\title{
PENGARUH PROPORSI KEPEMILIKAN SAHAM ASING DAN PROPORSI DIREKTUR DAN KOMISARIS ASING TERHADAP PENGHINDARAN PAJAK DI PERUSAHAAN MANUFAKTUR SEKTOR INDUSTRI BARANG KONSUMSI SUB SEKTOR MAKANAN DAN MINUMAN YANG TERDAFTAR DI BURSA EFEK INDONESIA
}

\author{
Gregorius Fx Erick Tofani Riberu \\ Program Studi Magister Manajemen Universitas Tarumanagara \\ rck.tofani@gmail.com
}

Masuk : 10-06-2020, revisi : 26-06-2020 diterima untuk diterbitkan : 29-06-2020

\begin{abstract}
The research aims to determine the impact of foreign investor's interests on tax avoidance in Consumer Goods- Manufacturing Companies, in particular the food and beverage sector, listed in Indonesia Stock Exchange during the periods from 2011 to 2016. The interests of foreign investors are measured by two variable which are the percentage of ownership by foreign investors and the percentage of foreign directors and commisoners on the board directors. The methodology used in this research is sampling method, tested by multiple linear regression. Tax avoidance is measured by two approaches, i.e. Effective Tax Rate and Book Tax Different. This research concludes that the percentage of ownership by foreign investors and the percentage of foreign directors and commisoners on board directors show no significant effect to the corporate tax avoidance
\end{abstract}

Keywords: Tax Avoidance, The Percentage of Ownership by Foreign Investors, The Percentage of Foreign Directors and Commisoners on The Board Directors, Effective Tax Rate, Book Tax Different, Multiple Linear Regression

Abstrak: Tujuan penulisan makalah ini adalah untuk mengetahui pengaruh proporsi kepemilikan saham asing dan proporsi direktur dan komisaris asing terhadap penghindaran pajak di perusahaan manufaktur sektor industri barang konsumsi sub sektor makanan dan minuman yang terdaftar di Bursa Efek Indonesia selama peiode tahun 2011 sampai dengan 2016. Teknik pengambilan sampel menggunakan metode purposive sampling, diuji dengan metode regresi linier berganda. Pengujian dilakukan dengan dua pendekatan yaitu Effective Tax Rate dan Book Tax Different. Berdasarkan hasil penelitian dapat disimpulkan bahwa dengan pendekatan ETR, proporsi kepemilikan saham asing tidak berpengaruh positif atas penghindaran pajak, namun proporsi direktur dan komisaris asing berpengaruh positif terhadap penghindaran pajak meskipun tidak signifikan. Sedangkan dengan pendekatan BTD proporsi kepemilikan saham asing bepengaruh positif terhadap penghindaran pajak meskipun tidak signifikan, dan proporsi direktur dan komisaris asing tidak berpengaruh positif terhadap penghindaran pajak.

Kata Kunci: Penghindaran Pajak, Proporsi Kepemilikan Saham Asing, Proporsi Direktur dan Komisaris Asing, Effective Tax Rate, Book Tax Different, Regresi Linier Berganda

\section{PENDAHULUAN}

Globalisasi yang menyediakan pasar internasional tidak hanya mendatangkan modal asing ke Indonesia, namun juga menghadirkan Sumber Daya Manusia dari negara lain yang menduduki posisi puncak di perusahaan yaitu menjabat Komisaris dan Direktur. Adanya kepemilikan saham asing, kehadiran komisaris dan direktur asing dalam perusahaan memberikan dampak ke perusahaan dalam upayanya mengoptimalkan usaha dan menghasilkan keuntungan termasuk dalam pemenuhan kewajiban perpajakan. Mengacu pada usaha perusahaan dalam memaksimalkan laba dan kewajibannya membayar pajak, setiap perusahaan 
memiliki strategi atau perencanaan dalam menghitung pajak agar keuntungan setelah pajak yang akan dinikmati oleh pemilik perusahaan tetap optimal. Strategi memaksimalkan laba bersih perusahaan dengan cara meminimalkan pembayaran pajak dilakukan dengan cara penghindaran pajak. Strategi atau rencana perusahaan, termasuk penghindaran pajak tersebut melibatkan segenap komponen yang dimiliki perusahaan, terutama pemegang saham, komisaris dan direktur. Penghindaran pajak merupakan cara yang dilakukan Wajib Pajak untuk memperkecil atau mengefisienkan beban pajak. Pada umumnya Wajib Pajak dapat memperkecil atau mengefisienkan beban pajak secara legal melalui penghindaran pajak (tax avoidance) atau secara ilegal melalui pengelakan pajak (tax evasion) (Gunadi, 2012). Menurut Lumbantoruan (1996), Perencanaan pajak atau tax planning tidak sesuai dengan kepribadian Indonesia karena pengelakan pajak baik yang legal maupun yang tidak sangat merugikan penerimaan negara. Dengan berkurangnya penerimaan negara dari pajak, tentunya berdampak langsung terhadap pembangunan dan upaya untuk meningkatkan kesejahteraan rakyat.

Di Indonesia, kepatuhan dan kesadaran Wajib Pajak dalam menunaikan kewajibannya masih rendah. Hal ini dapat diukur dari angka tax ratio di tahun 2014 sampai dengan 2016 yang masih berkisar 10\% sampai dengan 11\%. Mantan Menteri Keuangan Bambang Brojonegoro yang saat ini menjabat sebagai Menteri Riset, Teknologi dan Kepala Badan Riset Inovasi Nasional menyatakan bahwa "tax ratio Indonesia masih dibawah standar negaranegara ASEAN". Rendahnya tax ratio ini dipengaruhi beberapa faktor dan salah satunya disebabkan praktik penghindaran pajak yang dilakukan oleh Wajib Pajak Orang Pribadi maupun Badan Usaha. Badan usaha tersebut, dapat berupa perusahaan dalam negeri maupun yang sahamnya dimiliki oleh asing. Kepemilikan saham asing dan kehadiran komisaris dan direktur asing diduga memberikan pengaruh dalam penghindaran pajak. Penelitian ini dilakukan untuk meneliti pengaruh proporsi kepemilikan saham asing dan proposi direktur dan komisaris asing terhadap penghindaran pajak.

Data Bursa Efek Indonesia mencatat bahwa terdapat sembilan sektor usaha yang terdaftar di BEI, yaitu sektor pertanian, pertambangan, industri dasar dan kimia, aneka industri, industri barang konsumsi, properti dan real estate, infrastruktur, utilitas dan transportasi, keuangan dan perdagangan jasa dan investasi. Di setiap sektor industri terdapat sub-sub sektor yang mengklasifikasikan jenis usaha lebih spesifik. Salah satunya adalah di sektor industri barang konsumsi terdapat sub sektor makanan dan minuman yang jenis produk usahanya sangat dibutuhkan oleh orang banyak, dan termasuk yang dikonsumsi masyarakat perorangan dan rumah tangga. Industri makanan dan minuman merupakan salah satu sektor usaha yang diandalkan untuk memberikan kontribusi terhadap pertumbuhan nasional. Kementerian Perindustrian mencatat, sepanjang tahun 2018, indutri makanan dan minuman mampu tumbuh sebesar 7,91 persen atau melampaui pertumbuhan ekonomi nasional di angka 5,17 persen. Bahkan pertumbuhan produksi industri manufaktur besar dan sedang di Triwulan IV-2018 naik sebesar 3,90 persen (y-on-y) terhadap triwulan IV-2017, salah satunya disebabkan oleh meningkatnya produksi industri minuman yang mencapai 23,44 persen (Siaran Pers, 2019). Selanjutnya, industri makanan menjadi salah satu sektor yang menopang peningkatan nilai investasi nasional, yang pada tahun 2018 menyumbang hingga Rp 56,60 triliun, termasuk dalam keseluruhan nilai investasi di sektor manufaktur sebesar Rp 222,3 triliun.

Berdasarkan uraian di atas, peneliti tertarik untuk melakukan penelitian pengaruh proporsi kepemilikan saham asing dan proporsi direktur dan komisaris asing terhadap penghindaran pajak.

Tujuan dilakukannya penelitian ini adalah mengetahui pengaruh proporsi kepemilikan saham asing dan proporsi direktur dan komisaris asing di perusahaan terhadap penghindaran pajak pada perusahaan manufaktur sektor industri barang konsumsi sub sektor makanan dan minuman yang terdaftar di BEI tahun 2011 sampai dengan 2016. 


\section{LANDASAN TEORI}

Teori Stakeholder menyatakan bahwa perusahaan bukanlah entitas yang hanya beroperasi untuk kepentingannya sendiri namun harus memberikan manfaat bagi stakeholdernya (pemegang saham, kreditur, konsumen, supplier, pemerintah, masyarakat, dan pihak lain. Teori ini digunakan dalam penelitian karena praktik penghindaran pajak mempengaruhi hubungan perusahaan dengan stakeholdernya, terutama pemerintah. Penghindaran pajak mengakibatkan beban pajak perusahaan menjadi kecil sehingga penerimaan negara juga kecil. Dengan berkurangnya penerimaan negara dari pajak, tentunya berdampak langsung terhadap program-program pemerintah terutama pembangunan infrastruktur dan upaya untuk meningkatkan kesejahteraan rakyat.

Teori Agensi. Menurut Scott (2015) konsep teori agensi atau keagenan adalah hubungan atau kontrak antara prinsipal dan agen, dimana prinsipal adalah pihak yang mempekerjakan agen agar melakukan tugas untuk kepentingan prinsipal, sedangkan agen adalah pihak yang menjalankan kepentingan prinsipal. Teori agensi digunakan dalam penelitian ini, karena di antara prinsipal dan agen dapat terjadi perbedaan kepentingan terkait penghindaran pajak. Pihak agen sebagai pekerja dalam mengelola keuangan termasuk perpajakan bertujuan menghasilkan keuntungan yang besar. Namun meski menguntungkan, bagi principal sebagai pemilik perusahaan penghindaran pajak dapat menimbulkan hubungan tidak baik antara perusahaan dengan pemerintah, dan dapat menimbulkan persepsi negatif dari masyarakat.

Teori Legitimasi. Menurut Ghozali dan Chairi (2007), yang melandasi teori legitimasi adalah kontrak sosial yang terjadi antara perusahaan dengan masyarakat dimana perusahaan beroperasi dan menggunakan sumber ekonomi. Teori ini digunakan dalam penelitian karena praktik penghindaran pajak memengaruhi persepsi masyarakat terhadap perusahaan. Setiap entitas, termasuk perusahaan yang sahamnya dimiliki asing atau dipimpin oleh direktur dan komisaris asing memiliki kewajiban membayar pajak. Perusahaan yang tidak melakukan praktik penghindaran pajak berarti patuh terhadap kewajibannya. Kepemilikan asing dan kehadiran direktur dan komisaris asing harus mengedepankan kepentingan nasional, salah satu caranya adalah dengan mematuhi ketentuan yang berlaku di Indonesia agar perusahaan memilki kontribsi positif terhadap negara dan masyarakat.

Effective Tax Rate/ETR dalam penelitian ini sebagai proxy penghindaran pajak (model 1). ETR adalah pengukuran penghindaran pajak dengan cara membagi beban pajak dengan laba sebelum pajak. ETR menggambarkan rasio beban pajak perusahaan relatif terhadap laba sebelum pajak.

Book Tax Different/ BTD dalam penelitian ini sebagai proxy penghindaran pajak (model 2) adalah perbedaan antara laba kena pajak menurut ketentuan perpajakan dan pendapatan sebelum kena pajak menurut stadar akuntansi. Peraturan menurut akuntansi dan pajak memiliki tujuan yang berbeda, sehingga akan menimbulkan peluang terjadinya manajemen laba (Purwanto, 2016).

\section{KERANGKA TEORI DAN HIPOTESIS}

H10 : Proporsi kepemilikan saham asing (foreign1) tidak berpengaruh positif terhadap penghindaran pajak

H1A : Proporsi kepemilikan saham asing (foreign1) berpengaruh positif terhadap penghindaran pajak

H20 : Proporsi Direktur dan Komisaris Asing (foreign2) tidak berpengaruh positif terhadap penghindaran pajak

H2A : Proporsi Direktur dan Komisaris Asing (foreign2) berpengaruh positif terhadap penghindaran pajak

Penelitian ini menguji dua pendekatan atas Penghindaran Pajak (corporate tax avoidance) sebagai variabel dependen yaitu model 1 Effective Tax Rate (CTA1) dan model 2 Book Tax Different (CTA2) sehingga terdapat dua kerangka pemikiran dengan menggunakan lima variabel kontrol yaitu koneksi politik (x3), profitabilitas (x4), ukuran perusahaan (x5), leverage (x6) dan capital intensity (x7).

$$
\begin{aligned}
& \text { CTA } 1=\alpha+\beta 1 \times 1+\beta 2 \times 2+\beta 3 \times 3+\beta 4 \times 4+\beta 5 \text { sizex } 5+\beta 6 \text { levx } 6+\beta 7 \times 7+\varepsilon \\
& \text { CTA } 2=\alpha+\beta 1 \times 1+\beta 2 \times 2+\beta 3 \times 3+\beta 4 \times 4+\beta 5 \text { sizex } 5+\beta 6 \text { levx } 6+\beta 7 \times 7+\varepsilon
\end{aligned}
$$




\section{METODOLOGI PENELITIAN}

Penelitian ini merupakan jenis penelitian penjelasan (explanatory research) yaitu penelitian yang bertujuan untuk menjelaskan hubungan-hubungan antara satu variabel dengan variabel lainnya melalui pengujian hipotesis. Subjek penelitian ini adalah perusahaanperusahaan yang termasuk industri barang konsumsi sub sektor makanan dan minuman yang terdaftar di Bursa Efek Indonesia pada periode tahun 2011 sampai dengan 2016. Objek penelitian ini adalah variabel-variabel penelitian yang tercantum dalam data laporan keuangan dan laporan tahunan perusahaan manufaktur sektor industri barang konsumsi sub sektor makanan dan minuman yang terdaftar di BEI tahun 2011 sampai dengan 2016. Dari total populasi 16 perusahaan yang terdaftar di Bursa Efek Indonesia pada tahun 2011 sampai dengan 2016, yang memenuhi kriteria dan menjadi sampel adalah 10 perusahaan.

Sampel yang digunakan dalam penelitian ini didapatkan melalui purposive sampling yang telah melewati beberapa tahap. Tahap pertama adalah memilih seluruh perusahaan manufaktur sektor industri barang dan konsumsi sub sektor makanan dan minuman yang terdaftar di BEI selama enam tahun periode penelitian yaitu dari tahun 2011 sampai dengan 2016. Tahap kedua adalah mengeliminasi perusahaan manufaktur tersebut yang tidak selalu ada atau tidak konsisten terdaftar di BEI selama tahun penelitian. Tahap ketiga adalah yang tidak memiliki data keuangan lengkap yang dibutuhkan dalam penelitian. Tahap keempat adalah mengeliminasi perusahaan manufaktur tersebut yang mengalami kerugian operasi. Jangka waktu dalam penelitian ini adalah enam tahun pengamatan, yaitu dari tahun 2011 sampai dengan 2016.

Variabel Dependen adalah penghindaran pajak. Dalam penelitian ini pengujian akan dilakukan dengan dua pendekatan yaitu dengan Effective Tax Rate (ETR) dan Book Tax Different (BTD). Semakin tinggi nilai ETR/ BTD maka dapat dikatakan semakin patuh perusahaan. Sebaliknya semakin rendah nilai ETR/BTD, dapat dikatakan perusahaan terindikasi melakukan penghindaran pajak. periode 2011sampai dengan 2016. Terdapat dua variabel independen dalam penelitian ini yaitu proporsi kepemilikan saham asing dan proporsi direktur dan komisaris asing. Terdapat lima variabel kontrol dalam penelitian ini yaitu koneksi politik, profitabilitas, ukuran perusahaan, leverage dan capital intensity. Berdasarkan hipotesis, maka variabel-variabel yang terdapat dalam penelitian ini didefinisikan sebagai berikut:

\section{Tabel 1}

Definisi Operasional Variabel

\begin{tabular}{|c|c|c|}
\hline Variabel & Definisi & Pengukuran \\
\hline $\begin{array}{l}\text { Penghindaran Pajak } \\
\text { (ETR) }\end{array}$ & Rasio antara beban pajak terhadap laba sebelum pajak & $\begin{array}{c}\text { Beban Pajak } \\
\text { Laba sebelum Pajak }\end{array}$ \\
\hline $\begin{array}{l}\text { Penghindaran Pajak } \\
\text { (BTD) }\end{array}$ & $\begin{array}{l}\text { Rasio laba kena pajak menurut ketentuan perpajakan terhadap } \\
\text { pendapatan sebelum kena pajak menurut stadar akuntansi }\end{array}$ & $\begin{array}{l}\text { (Laba komersial } \\
\text { sebelum pajak-Laba } \\
\text { Fiskal) / } \\
\text { Total Aset }\end{array}$ \\
\hline $\begin{array}{l}\text { Proporsi } \\
\text { Kepemilikan Saham } \\
\text { Asing }\end{array}$ & Perbandingan kepemilikan saham asing terhadap keseluruhan saham & $\begin{array}{l}\text { Kepemilikan Saham } \\
\text { Dimiliki Asing } \\
\text { Total Saham Beredar }\end{array}$ \\
\hline $\begin{array}{l}\text { Proporsi Direktur dan } \\
\text { Komisaris Asing }\end{array}$ & $\begin{array}{l}\text { Perbanidngan direktur dan komisaris asing terhadap keseluruhan } \\
\text { direkur dan komisaris }\end{array}$ & $\begin{array}{c}\text { Dir Asing\&Kom } \\
\underline{\text { Asing Total Dir\&Kom }}\end{array}$ \\
\hline Koneksi Politik & 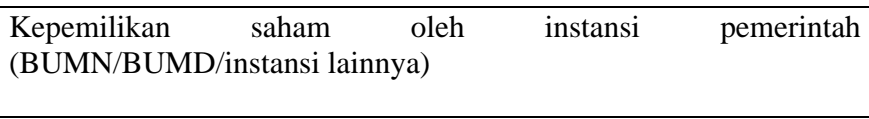 & $\begin{array}{c}\text { Saham Dimiliki } \\
\text { Pemerintah / } \\
\text { Total Saham Beredar } \\
\end{array}$ \\
\hline Profitabilitas & ROA, yaitu perbandingan laba sebelum pajak terhadap total aset. & $\frac{\text { Laba Sebelum Pajak }}{\text { Total Aset }}$ \\
\hline Ukuran Perusahaan & $\begin{array}{l}\text { Ukuran besar kecilnya perusahaan yang nampak dalam nilai total } \\
\text { asset perusahaan pada neraca akhir tahun, dan diukur dengan } \\
\text { logaritma natural dari nilai tersebut. }\end{array}$ & Size $=\operatorname{Ln}($ Total Asset $)$ \\
\hline Leverage & $\begin{array}{l}\text { Rasio keuangan yang menggambarkan hubungan antara hutang } \\
\text { perusahaan terhadap modal maupun asset }\end{array}$ & $\frac{\text { Hutang Jk. Panjang }}{\text { Modal }}$ \\
\hline Capital Intensity & $\begin{array}{l}\text { Ukuran efisiensi sebuah perusahaan dalam penggunaan asset fisik } \\
\text { atau asset keuangannya untuk menghasilkan profit }\end{array}$ & $\frac{\text { Aset Tetap }}{\text { Total Aset }}$ \\
\hline
\end{tabular}




\section{PEMBAHASAN}

Berdasarkan pengolahan data, persamaan regresi untuk model 1 yang menggunakan random effect model adalah sebagai berikut:

CTA $1_{\mathrm{it}}=-0.000577+0.022939$ foreign $_{1 \mathrm{it}}-0.0408571$ foreign $2_{\mathrm{it}}+0.333413$ polcon $_{\mathrm{it}}-$ 0.013970 profit $_{\mathrm{it}}+0.021886$ size $_{\mathrm{it}}-0.081376$ lev $_{\mathrm{it}}-0,030585$ capint $_{\mathrm{it}}+\varepsilon_{\mathrm{it}}$

Pada variabel foreignl sebagai proporsi kepemilikan saham asing, terlihat bahwa foreign1 memiliki koefisien positif dengan nilai 0.022939, yang berarti bahwa setiap kenaikan 1 poin atas proporsi kepemilikan saham asing akan diikuti kenaikan sebesar 0.022939 CTA1. Dapat dikatakan bahwa proporsi kepemilikan saham asing tidak berpengaruh terhadap penghindaran pajak. Disimpulkan bahwa jika proporsi kepemilikan saham asing bertambah maka perusahaan semakin tidak menghindari pajak.

Hasil penelitian ini bertentangan dengan penelitian Li (2018) yang menyatakan perusahaan dengan kepemilikan saham asing yang besar akan lebih menghindari pajak. Namun penelitian ini sejalan dengan penelitian Idzni dan Purwanto (2017) yang menghasilkan interpretasi bahwa kepemilikan saham asing tidak memiliki pengaruh terhadap penghindaran pajak.

Pada model CTA1 proporsi kepemilikan saham asing dinyatakan tidak berpengaruh terhadap penghindaran pajak, hal ini dapat disebabkan bahwa di perusahaan terbuka (tbk) seluruh pemegang saham memiliki tanggung jawab terhadap stakeholder, termasuk kepada pemerintah. Kepemilikan saham asing di perusahaan tidak bertujuan untuk memperoleh keuntungan dari penghindaran pajak yang dapat merugikan negara dimana tempat perusahaan berdomisili, hal ini dapat menimbulkan hubungan tidak baik dengan stakeholder terutama pemerintah. Dengan tidak menghindari pajak maka perusahaan memperoleh legitimasi, bahwa kehadirannya memberikan dampak positif dan tidak melanggar ketentuan yang berlaku.

Pada variabel foreign2, terlihat bahwa foreign2 memiliki koefisien negatif dengan nilai 0.040857, yang berarti bahwa setiap kenaikan 1 poin atas proporsi direktur dan komisaris asing akan diikuti penurunan sebesar 0.040857 CTA1. Dapat dikatakan bahwa foreign2 berpengaruh positif terhadap penghindaran pajak namun dengan nilai signifikansi lebih besar dari 0.05 yang berarti tidak signifikan. Dengan kata lain, foreign2 tidak berpengaruh terhadap penghindaran pajak.

Pada model CTA1 proporsi direktur dan komisaris asing dinyatakan berpengaruh positif terhadap penghindaran pajak namun tidak signifikan, dengan kata lain proporsi direktur dan komisaris asing tidak berpengaruh terhadap penghindaran pajak. Hal ini dapat disebabkan bahwa direktur dan komisaris mendapatkan wewenang menjalankan perusahaan dari pemegang saham untuk memperoleh keuntungan sebesar-besarnya, namun kewenangan yang diperoleh terbatas tidak untuk menghindari pajak. Pengaruh yang tidak signifikan ini dapat juga disebabkan bahwa perusaahn menjaga reputasinya agar mendapatkan legitimasi atau nilai yang positif di masyarakat dan pemerintah sehingga dikelola dengan mentaati ketentuan yang berlaku. Pada model CTA1, dengan menggunakan random effect model, tidak ada variabel kontrol yang berpengaruh signifikan terhadap variabel dependen.

Persamaan regresi untuk model 2 yang menggunakan random effect model adalah sebagai berikut:

$$
\begin{aligned}
\mathrm{CTA} 2_{\mathrm{it}}= & 0.136721-0.026158 \text { foreign }_{\text {it }}+0.039727 \text { foreign }_{\mathrm{it}}-0.141931 \text { polcon }_{\text {it }}- \\
& 0.022157 \text { profit }_{\mathrm{it}}-0.003992 \text { size }_{\mathrm{it}}+0.004599 \text { lev }_{\mathrm{it}}-0,031985 \text { capint }_{\mathrm{it}}+\varepsilon_{\mathrm{it}}
\end{aligned}
$$

Pada variabel foreign1, terlihat bahwa foreign1 memiliki koefisien negatif dengan nilai 0.026158, yang berarti bahwa setiap kenaikan 1 poin atas proporsi kepemilikan saham asing akan diikuti penurunan sebesar 0.026158 CTA2. Dapat dikatakan bahwa foreignl berpengaruh positif terhadap penghindaran pajak, namun dengan nilai signifikansi di atas 0.05 sehingga pengaruhnya tidak signifikan. Dengan kata lain, foreignl tidak berpengaruh terhadap penghindaran pajak.

Hasil dari penelitian ini bertentangan dengan penelitian Nadhir dan Christine (2015) yang menyatakan bahwa semakin tinggi proporsi kepemilikan saham asing di sebuah perusahaan 
maka perusahaan tersebut akan semakian menghindari pajak. Namun penelitian ini sejalan dengan penelitian Hidayat dan Mulda (2019) dan juga mendukung penelitian Idzni dan Purwanto (2017) yang menghasilkan interpretasi bahwa kepemilikan saham asing tidak memiliki pengaruh terhadap penghindaran pajak.

Pada model CTA2 proporsi kepemilikan saham asing dinyatakan tidak berpengaruh terhadap penghindaran pajak, hal ini dapat disebabkan bahwa di perusahaan terbuka (tbk) seluruh pemegang saham memiliki tanggung jawab terhadap stakeholder, termasuk kepada pemerintah. Kepemilikan saham asing di perusahaan tidak bertujuan untuk memperoleh keuntungan dari penghindaran pajak yang dapat merugikan negara dimana tempat perusahaan berdomisili, hal ini dapat menimbulkan hubungan tidak baik dengan stakeholder terutama pemerintah. Dengan tidak menghindari pajak maka perusahaan memperoleh legitimasi, bahwa kehadirannya memberikan dampak positif dan tidak melanggar ketentuan yang berlaku.

Pada variabel foreign2, terlihat bahwa foreign2 memiliki koefisien positif dengan nilai 0.39727, yang berarti bahwa setiap kenaikan 1 poin atas proporsi direktur dan komisaris asing akan diikuti kenaikan sebesar 0.039727 CTA2. Dapat dikatakan bahwa foreign2 berpengaruh negatif terhadap penghindaran pajak. Yang artinya foreign2 tidak berpengaruh terhadap penghindaran pajak.

Pada model CTA2 proporsi direktur dan komisaris asing dinyatakan berpengaruh negatif terhadap penghindaran pajak, dengan kata lain proporsi direktur dan komisaris asing tidak berpengaruh terhadap penghindaran pajak. Hal ini dapat disebabkan bahwa direktur dan komisaris mendapatkan wewenang menjalankan perusahaan dari pemegang saham untuk memperoleh keuntungan sebesar-besarnya, namun kewenangan yang diperoleh terbatas tidak untuk menghindari pajak. Dan seturut teori legitimasi, pengelola perusahaan termasuk direktur dan komisaris asing menjaga reputasi perusahaannya agar memperoleh legitimasi di tengah masyarakat dan pemerintah. Pada model CTA2 dengan menggunakan random effect model, tidak ada variabel kontrol yang berpengaruh signifikan terhadap variabel dependen.

\section{KESIMPULAN}

1. Pada model 1 (ETR) Proporsi kepemilikan saham asing berpengaruh negatif terhadap penghindaran pajak namun proporsi direktur dan komisaris asing berpengaruh positif tetapi tidak signifikan terhadap penghindaran pajak.

2. Pada model 2 (BTD) Proporsi kepemilikan saham asing berpengaruh positif tetapi tidak signifikan terhadap penghindaran pajak namun proporsi direktur dan komisaris asing berpengaruh negatif terhadap penghindaran pajak.

3. Koneksi Politik, profitabilitas, ukuran perusahaan dan capital intensity sebagai variabel control berpengaruh positif terhadap penghindaran pajak namun masing-masing pengaruhnya tidak signifikan, sedangkan leverage berpengaruh negatif terhadap penghindaran pajak.

\section{DAFTAR PUSTAKA}

Gunadi. (2012). Akuntansi Pajak Sesuai dengan Undang-undang Pajak Baru. Jakarta: PT Gramedia Widasarana Indonesia.

Hidayat, M., \& Mulda, R. (2019). Pengaruh book tax gap dan kepemilikan asing terhadap penghindaran pajak dan analisis kebijakan pemerintah terkait penghindaran pajak. Jurnal Dimensi Unika, 8(3).

Idzni, I., \& Purwanto, A. (2017). Pengaruh ketertarikan investor asing dan kepemilikan institusional terhadap penghindaran pajak perusahaan. Diponegoro Journal of Accounting, 6(1).

Li, X (2018). The Impact of Foreign Operations and Foreign Ownership on Corporate Tax Avoidance in The Australian Dividend Imputation System. A Thesis. Australian National University 